\title{
Pengaruh Struktur Modal, Profitabilitas, Likuiditas, dan Ukuran Perusahaan terhadap Nilai Perusahaan (Studi Empiris pada Perusahaan Infrastruktur, Utilitas, dan Transportasi yang Terdaftar di Bursa Efek Indonesia Periode 2015-2018)
}

\author{
Tunggul Priyatama*, Eka Pratini \\ Fakultas Ekonomika Dan Bisnis, Universitas Wijayakusuma Purwokerto \\ *correspondence email: tunggul25@gmail.com
}

\begin{abstract}
Abstrak. Tujuan penelitian ini adalah untuk mengalaisis pengaruh struktur modal, profitabilitas, likuiditas, dan ukuran perusahaan terhadap nilai perusahaan pada perusahaan infrastruktur, utilitas dan transportasi yang terdaftar di Bursa Efek Indonesia periode 2015-2018. Teknik pengambilan sampel yang digunakan adalah purposive sampling, sampel perusahaan yang diperoleh terdiri dari 24 perusahaan infrastruktur, utilitas dan transportasi yang terdaftar di BEI tahun 2015-2018. Metode penelitian menggunakan regresi linier berganda dengan pendekatan data panel. Hasil penelitian menunjukkan bahwa struktur modal dan profitabilitas berpengaruh positif signifikan terhadap nilai perusahaan pada perusahaan infrastruktur, utilitas dan transportasi yang terdaftar di Bursa Efek Indonesia periode 2015-2018. Likuiditas dan ukuran perusahaan berpengaruh negatif signifikan terhadap nilai perusahaan infrastruktur, utilitas dan transportasi yang terdaftar di Bursa Efek Indonesia periode 2015-2018. Implikasi dari penelitian ini antara lain bahwa tambahan hutang pada struktur modal perusahaan dapat menjadi sinyal positif bagi investor yang dapat meningkatkan nilai perusahaan karena tambahan hutang pada suatu perusahaan dapat digunakan untuk tambahan dana investasi dan penghematan pajak perusahaan. Kemudian peningkatan nilai profitabilitas dapat menunjukkan prospek perusahaan yang baik bagi investor karena banyak investor yang tertarik pada perusahaan yang memiliki profitabilitas yang baik, dan berdampak pada peningkatan permintaan saham dan nilai perusahaan.
\end{abstract}

Kata kunci: Struktur Modal, Profitabilitas, Likuiditas, Ukuran Perusahaan, Nilai Perusahaan.

Abstract. The purpose of this study was to determine the effect of capital structure, profitability, liquidity, and firm size on firm value of the company on infrastructure, utilities and transportation companies listed on the Indonesia Stock Exchange for the period 2015- 2018. The sampling technique used was purposive sampling, the sample of companies obtained consisted of 24 infrastructure, utilities and transportation companies listed on the Stock Exchange in 2015-2018. The research method uses multiple linear regression with a panel data approach. The results show that capital structure and profitability have a significant positive effect on the firm value of infrastructure, utilities and transportation companies listed on the Indonesia Stock Exchange for the period 2015-2018. Liquidity and firm size have a significant negative effect onthe firm value of infrastructure, utilities and transportation companies listed on the Indonesia Stock Exchange for the period 2015-2018. The implications of this study include that additional debt in the company's capital structure can be a positive signal to investors that can increase company value because additional debt in a company can be used for additional investment funds and corporate tax savings. Then, an increase in the value of profitability can show investors good prospects for the company because many investors are attracted to companies that have good profitability, and have an effect on increasing share demand and company value.

Keywords: capital structure, profitability, liquidity, firm size, firm value.

\section{PENDAHULUAN}

Perusahaan merupakan lembaga ekonomi yang memiliki tujuan jangka panjang yaitu untuk memaksimalkan nilai perusahaan. Nilai perusahaan yang baik dapat menjadi sesuatu yang menarik bagi para pemangku kepentingan untuk dapat memulai atau mengembangkan investasi pada perusahaan tersebut. Disamping itu, pemangku kepentingan juga dapat menerima sinyal bahwa perusahaan telah menunjukkan kinerja seperti yang diharapkan. Kemampuan perusahaan untuk menghasilkan nilai perusahaan yang baik dipengaruhi oleh kemampuan manajemen dalam mengelola perusahaan. Perusahaan mengharapkan manajer keuangan dapat melakukan peningkatan kinerja yang lebih baik bagi perusahaan untuk menciptakan kemakmuran bagi pemilik dan pemegang saham. Kinerja perusahaan yang baik akan mencerminkan nilai perusahaan yang baik juga, hal tersebut dapat tercermin dari harga sahamnya (Anisyah dan Purwohandoko, 2017). Nilai perusahaan dapat dikatakan sebagai pemahaman investor mengenai seberapa besar tingkatan keberhasilan suatu perusahaan yang sering dikaitkan dengan harga saham perusahaan (Fauzi dan Aji, 2018).

Berkaitan dengan perihal nilai perusahaan, ada suatu kondisi yang menarik pada sektor usaha infrastruktur, utilitas, dan transportasi yang ada di bursa efek. Berdasarkan data Bursa Efek Indonesia (BEI) hingga 9 Maret 2015, sektor saham infrastruktur, utilitas, dan transportasi turun 2,37\% (Deil, 2015). Koreksi indeks saham sektor ini berlanjut pada periode berikutnya yang nampaknya dipicu oleh turunnya harga saham PT Telekomunikasi Indonesia, Tbk. (TLKM) (Kevin, 2018). Mengutip publikasi dari halaman resmi Bursa Efek Indonesia (BEI), kapitalisasi pasar TLKM 
Tunggul Priyatama dan Eka Pratini, Pengaruh Struktur Modal, Profitabilitas, Likuiditas, dan Ukuran Perusahaan terhadap Nilai Perusahaan (Studi Empiris pada Perusahaan Infrastruktur, Utilitas, dan Transportasi yang Terdaftar di Bursa Efek Indonesia Periode 2015-2018)

per akhir 2017 adalah sebesar Rp 447,5 triliun atau setara dengan $55 \%$ dari total kapitalisasi pasar sektor infrastruktur, utilitas, dan transportasi (Kevin, 2018). Hal tersebut mengakibatkan pergerakan saham TLKM akan sangat mempengaruhi pergerakan indeks sektoralnya. Sepanjang kuartal 1, saham TLKM turun sebesar 18,92 $\%$ (Kevin, 2018).

Fenomena yang ditemui pada perusahaan di sektor infrastruktur, utilitas, dan transportasi menunjukkan adanya penurunan nilai perusahaan yang tercermin melalui harga sahamnya. Karena pentingnya nilai perusahaan ini bagi para pemangku kepentingan untuk melihat kinerja perusahaan dan prospek ke depannya, penurunan nilai saham yang terjadi di sektor tersebut menjadi perhatian penulis untuk menggali lebih dalam mengenai berbagai faktor yang dapat mempengaruhi nilai perusahaan. Berdasarkan pengamatan beberapa literatur, penulis melihat ada beberapa faktor yang dapat mempengaruhi nilai perusahaan antara lain; struktur modal, profitabilitas, likuiditas, dan ukuran perusahaan.

Struktur modal menjadi faktor pertama yang diduga dapat mempengaruhi nilai perusahaan. Struktur modal merupakan perimbangan antara modal asing dengan modal sendiri (Riyanto, 2008). Nilai perusahaan bagi perusahaan yang melibatkan hutang akan lebih tinggi dibandingkan dengan perusahan yang tanpa hutang (Dewi dan Wirajaya, 2013). Hal tersebut dikarenakan adanya penghematan pajak yang terjadi, sehingga laba bersih yang menjadi hak pemegang saham akan menjadi lebih besar dibandingkan dengan perusahaan yang tidak menggunakan hutang (Dewi dan Wirajaya, 2013). Penelitian terdahulu yang menyatakan struktur modal berpengaruh positif signifikan terhadap nilai perusahaan antara lain Asif dan Aziz (2016), Kamila dan Yuniati (2017), Chasanah dan Adhi (2017), Utami, Santoso, dan Pranaditya (2017), dan Mawarni dan Triyonowati (2017). Sedangkan penelitian terdahulu yang menyatakan struktur modal berpengaruh negatif signifikan terhadap nilai perusahaan antara lain Fauzi dan Aji (2018), Utomo dan Christy (2017) dan Kurniasih, dan Ruzikna (2017). Kemudian ada juga penelitian terdahulu yang menyatakan struktur modal tidak berpengaruh signifikan terhadap nilai perusahaan adalah Suranto, Nangoi dan Walandouw (2017).

Faktor kedua yang diduga dapat mempengaruhi nilai perusahaan diperankan oleh profitabilitas. Profitabilitas adalah kemampuan perusahaan menghasilkan laba atau ukuran efektivitas pengelolaan manajemen perusahaan (Wiagustini, 2010). Profitabilitas yang tinggi menunjukkan prospek perusahaan di masa mendatang akan menguntungkan bagi investor sehingga investor akan tertarik, yang mengakibatkan nilai perusahaan meningkat (Kusumayanti, 2016). Penelitian terdahulu yang menyatakan bahwa profitabilitas berpengaruh positif signifikan terhadap nilai perusahaan antara lain Sabrin, Sarita, Takdir dan Sujono (2016),
Sucuahi dan Cambarihan (2016), Sari dan Priyadi (2016), Chasanah dan Adhi (2017), dan Oktaviarni, Murni dan Suprayitno (2019). Sedangkan penelitian terdahulu yang menyatakan profitabilitas berpengaruh negatif signifikan terhadap nilai perusahaan antara lain Fauzi dan Aji (2018) dan Utami, Santoso, dan Pranaditya (2017). Kemudian ada juga penelitian terdahulu yang menyatakan profitabilitas tidak berpengaruh signifikan terhadap nilai perusahaan adalah Kamila dan Yuniati (2017).

Likuiditas juga diduga sebagai faktor ketiga yang dapat mempengaruhi nilai perusahaan. Likuiditas adalah kemampuan perusahaan dalam memenuhi kewajiban jangka pendeknya (Chasanah dan Adhi, 2017). Perusahaan yang memiliki likuiditas yang baik maka dianggap memiliki kinerja yang baik oleh investor. Hal ini dapat menarik investor untuk menanamkan modalnya pada perusahaan (Putra dan Lestari, 2016). Penelitian terdahulu yang menyatakan bahwa likuiditas berpengaruh positif signifikan terhadap nilai perusahaan antara lain Oktaviarni, Murni dan Suprayitno (2019), Putra dan Lestari (2016), Deli dan Kurnia (2017) dan Gunawan, Pituringsih, Widyastuti (2018). Sedangkan hasil penelitian Wijaya dan Purnawati (2013), Yuliana (2016), dan Andriani dan Rudianto (2019) menunjukkan pengaruh negatif signifikan. Kemudian, ada juga hasil penelitian yang menyatakan bahwa likuiditas tidak berpengaruh signifikan terhadap nilai perusahaan anara lain Chasanah dan Adhi (2017).

Ukuran perusahaan muncul sebagai faktor keempat pada penelitian ini yang diduga dapat mempengaruhi nilai perusahaan. Ukuran perusahaan menggambarkan besar kecilnya suatu perusahaan yang ditunjukkan pada total aktiva, jumlah penjualan, dan rata-rata penjualan (Riyanto, 2008). Semakin besar ukuran perusahaan yang dimiliki maka akan semakin banyak investor yang menaruh perhatian pada perusahaan (Kamila dan Yuniati, 2017). Hal tersebut, dikarenakan perusahaan mencerminkan perkembangan dan pertumbuhan yang baik sehingga meningkatkan nilai dari suatu perusahaan. Penelitian terdahulu yang menyatakan ukuran perusahaan positif signifikan terhadap nilai perusahaan antara lain Tui, Nurnajamuddin, Sufri dan Nirwana (2017), Mawarni dan Triyonowati (2017), Sari dan Priyadi (2016) dan Oktaviarni, Murni dan Suprayitno (2019). Sedangkan penelitian terdahulu yang menyatakan ukuran perusahaan berpengaruh negatif signifikan terhadap nilai perusahaan antara lain Kamila dan Yuniati (2017), Utomo dan Christy (2017), Panggabean (2018), dan Ramdhonah, Solikin, dan Sari (2019). Kemudian ada juga penelitian terdahulu yang menyatakan ukuran perusahaan tidak berpengaruh terhadap nilai perusahaan dari peneliti Fauzi dan Aji (2018) dan Utami, Santoso, dan Pranaditya (2017).

Adanya fenomena penurunan harga saham pada 
Tunggul Priyatama dan Eka Pratini, Pengaruh Struktur Modal, Profitabilitas, Likuiditas, dan Ukuran Perusahaan terhadap Nilai Perusahaan (Studi Empiris pada Perusahaan Infrastruktur, Utilitas, dan Transportasi yang Terdaftar di Bursa Efek Indonesia Periode 2015-2018)

perusahaan infrastruktur, utilitas, dan transportasi yang terdaftar di Bursa Efek Indonesia periode 2015-2018 dan hasil penelitian terdahulu yang masih kontradiktif menjadi poin penting diperlukannya penelitian lebih lanjut. Penelitian ini juga memiliki perbedaan dengan penelitian-penelitian sebelumnya. Perbedaannya terletak pada subjek penelitian yang diteliti dan periode yang digunakan. Subjek penelitian ini adalah perusahaan infrastruktur, utilitas, dan transportasi yang terdaftar di Bursa Efek Indonesia dan periode pengamatan dilakukan pada tahun 2015- 2018. Dengan demikian, penelitian ini bertujuan untuk menganalisis pengaruh struktur modal, profitabilitas, likuiditas, dan ukuran perusahaan terhadap nilai perusahaan yang ada pada perusahaan infrastruktur, utilitas, dan transportasi yang terdaftar di Bursa Efek Indonesia periode 2015-2018.

Penelitian ini dilandasi dengan teori sinyal (signaling theory) yang dipelopori oleh Spence (1973), dalam essay yang berjudul Job Market Sinaling. Secara singkat, Spence (1973), mengungkapkan bahwa teori ini membahas mengenai isyarat atau sinyal dari pihak pemilik informasi (dalam hal ini adalah manajemen perusahaan) yang berusaha memberikan informasi yang relevan kepada pihak penerima (dalam hal ini investor). Pihak penerima informasi kemudian dapat memanfaatkan informasi tersebut untuk menyesuaikan perilakunya sesuai dengan informasi yang dipahaminya. Ross (1977), mengembangkan teori sinyal tersebut dengan mengungkapkan bahwa teori sinyal dibangun berdasarkan adanya informasi asimetris antara informasi dari manajemen dan informasi dari investor. Teori ini berdasarkan pemikiran bahwa manajemen akan mengiformasikan kepada investor ketika ada informasi baik yang berkaitan dengan perusahaan seperti peningkatan nilai perusahaan. Widiastari dan Yasa (2018), teori sinyal menjelaskan bahwa perusahaan didorong untuk dapat memberikan informasi laporan keuangannya kepada pihak eksternal (investor dan kreditor) untuk mencegah ataupun mengurangi terjadinya asimetri informasi. Untuk menghindari asimetri informasi, pihak internal mengeluarkan laporan tahunan sebagai sinyal kepada para investor mengenai prospek perusahaan kedepannya dan berpengaruh pada keputusan investasi dari para investor (Sari dan Priyadi, 2016). Contoh kabar baik (good news) dalam laporan tahunan adalah ketika berbagai indikator kebijakan ataupun indikator kinerja dipandang ideal dan prospektif bagi para investor. Katakanlah profitabilitas, ketika profitabilitas perusahaan mengalami kenaikan dari tahun ke tahun, maka hal tersebut akan dapat memberikan sinyal baik kepada publik dan akan mempengaruhi fluktuasi harga saham perusahaan ke arah positif. Jika sinyal perusahaan menginformasikan kabar baik maka harga saham akan naik, namun sebaliknya jika perusahaan menginformasikan kabar buruk maka saham akan turun (Sari dan Priyadi, 2016).

\section{METODE}

Jenis penelitian yang digunakan dalam penelitian ini adalah penelitian kuantitatif. Objek penelitian ini adalah struktur modal, profitabilitas, likuiditas, ukuran perusahaan, dan nilai perusahaan pada perusahaan infrastruktur, utilitas, dan transportasi yang terdaftar di Bursa Efek Indonesia periode 2015-2018. Data diperoleh melalui laporan tahunan perusahaan yang dapat diakses di website resmi idx. Populasi dalam penelitian ini adalah semua perusahaan infrastruktur, utilitas, dan transportasi yang terdaftar di Bursa Efek Indonesia. Sampel yang digunakan dalam penelitian ini sebanyak 24 perusahaan infrastruktur, utilitas, dan transportasi yang di Bursa Efek Indonesia dengan menggunakan metode purposive sampling. Jumlah tahun penelitian adalah 4 tahun, maka total data penelitian adalah 96 perusahaan.

Tabel 1. Definisi Operasional Variabel

\begin{tabular}{|c|c|c|c|}
\hline No & Variabel & Definisi & Satuan \\
\hline 1 & $\begin{array}{l}\text { Nilai Perusahaan, } \\
\text { Menggunakan proksi Rasio Price } \\
\text { to Book Value (PBV) }\end{array}$ & PBV $=\frac{\text { Harga per lembar saham }}{\text { Nilai buhu per lembar sahar }}$ & Kali \\
\hline 2 & $\begin{array}{l}\text { Struktur Modal, } \\
\text { Menggunakan proksi } \\
\text { Debt to Equity Ratio (DER) }\end{array}$ & DER $=\frac{\text { Total Dabt }}{\text { Total Equity }} \times 100 \%$ & Persen \\
\hline 3 & $\begin{array}{l}\text { Profitabilitas, } \\
\text { Menggunakan proksi } \\
\text { Rasio Return OnAssets (ROA) }\end{array}$ & ROA $=\frac{\text { Laba bersih setelah pajal }}{\text { Total Aset }} \times 100 \%$ & Persen \\
\hline 4 & $\begin{array}{l}\text { Likuiditas, } \\
\text { Menggunakan proksi Rasio } \\
\text { Current Ratio (CR) }\end{array}$ & $\mathrm{CR}=\frac{\text { Current.Auset }}{\text { CurentLiability }} \times 100 \%$ & Persen \\
\hline 5 & $\begin{array}{l}\text { Ukuran Perusahaan, } \\
\text { Menggunakan proksi nilai } \\
\text { logaritma natural dari total aset }\end{array}$ & Ukuran Perusahaan $=$ Ln . Total Aset & Satuan \\
\hline
\end{tabular}


Tunggul Priyatama dan Eka Pratini, Pengaruh Struktur Modal, Profitabilitas, Likuiditas, dan Ukuran Perusahaan terhadap Nilai Perusahaan (Studi Empiris pada Perusahaan Infrastruktur, Utilitas, dan Transportasi yang Terdaftar di Bursa Efek Indonesia Periode 2015-2018)

digunakan dalam penelitian ini merupakan gabungan antara data time series (runtun waktu) dan data cross section (data silang). Uji regresi data panel digunakan untuk mengetahui hubungan antara variabel independen yang terdiri dari struktur modal, profitabilitas, likuiditas, dan ukuran perusahaan terhadap variabel dependen nilai perusahaan. Proses analisis regresi data panel pada penelitian ini menggunakan software eviews 9. Adapun persamaan regresi data panel pada penelitian ini adalah sebagai berikut,

$$
\begin{aligned}
& Y=\alpha+b_{1} X_{1 i t}+b_{2} X_{2 i t}+b_{3} X_{3 i t}+b_{4} X_{4 i t}+e \\
& \text { Keterangan : } \\
& \mathrm{Y}=\text { Nilai perusahaan } \\
& \text { a } \quad=\text { Konstanta } \\
& \mathrm{X}_{1} \quad=\text { Struktur modal } \\
& \mathrm{X}_{2} \quad=\text { Profitabilitas } \\
& \mathrm{X}_{3} \quad=\text { Likuiditas } \\
& \mathrm{X}_{4} \quad=\text { Ukuran perusahaan } \\
& \mathrm{b}_{1}, \mathrm{~b}_{2}, \mathrm{~b}_{3}, \mathrm{~b}_{4} \quad=\text { Koefisien Regresi } \\
& \mathrm{e}=\text { Standard eror } \\
& \mathrm{i}=\text { Unit perusahaan (cross section) } \\
& \mathrm{t}=\text { Periode Waktu (time series) }
\end{aligned}
$$

Teknik analisis data panel dalam penelitian ini dapat dilakukan dengan metode common effect, fixed effect dan random effect, sedangkan untuk menentukan metode mana yang lebih sesuai dengan penelitian ini maka digunakan Uji Chow, Uji Hausman, dan Uji Lagrange Multiplier (Gujarati dan Porter, 2010). Uji asumsi klasik terhadap model regresi yang digunakan, dilakukan agar dapat mengetahui apakah model regresi tersebut merupakan model regresi yang baik atau tidak, model penelitian ini uji asumsi klasik yang digunakan adalah uji normalitas, multikolineritas, heteroskedastisitas, dan autokorelasi (Gujarati dan Porter, 2010).

\section{HASIL DAN PEMBAHASAN}

Dalam membentuk persamaan regresi linear, perlu dilakukan analisis dengan menggunakan tiga metode yaitu metode Common Effect Model, Fixed Effect Model dan Random Effect Model. Dari ketiga metode selanjutnya akan dipilih satu dari tiga metode yang terbaik untuk analisis data ini. Untuk mengetahui pengaruh struktur modal, profitabilitas, likuiditas, dan ukuran perusahaan terhadap nilai perusahaan digunakan model regresi data panel dengan pengolahan program Eviews-9. Berdasarkan analisis regresi liner berganda dan uji kecocokan model dengan menggunakan program Eviews 9, model yang dipilih adalah Common Effect Model sehingga diperoleh hasil persamaan berikut ini:

$$
\begin{gathered}
Y=a+b 1 X 1 i t+b 2 X 2 i t+b 3 X 3 i t+b 4 X 4 i t+b 5 X 5 i t \\
Y=5,479206+0,459304 X_{1 i t}+0,062007 X_{2 i t}- \\
0,003185 X_{3 i t}-0,126623 X_{4 i t}
\end{gathered}
$$

Persamaan model regresi tersebut memberikan arti sebagai berikut:

$\mathrm{a}=5,479206$ menunjukkan bilangan konstanta bernilai positif yang berarti apabila variabel struktur modal, profitabilitas, likuiditas, dan ukuran perusahaan bernilai nol (0), maka nilai perusahaan sebesar 5,479206\%. Nilai konstanta yang positif menunjukkan nilai perusahaan baik.

$\mathrm{b}_{1}=0,459304$ menunjukkan koefisien regresi struktur modal bernilai positif terhadap nilai perusahaan. Artinya apabila variabel struktur modal meningkat sebesar satu \%, maka nilai perusahaan akan meningkat sebesar 0,459304 \% dengan asumsi variabel profitabilitas, likuiditas, dan ukuran perusahaan konstan. Nilai regresi yang positif tersebut berarti terdapat pengaruh antara struktur modal terhadap nilai perusahaan, atau semakin tinggi struktur modal maka nilai perusahaan akan semakin meningkat.

$\mathrm{b}_{2}=0,062007$ menunjukkan koefisien regresi profitabilitas bernilai positif terhadap nilai perusahaan. Artinya apabila variabel profitabilitas meningkat sebesar satu \%, maka nilai perusahaan akan meningkat sebesar 0,062007\% dengan asumsi variabel struktur modal, likuiditas, dan ukuran perusahaan konstan. Nilai regresi yang positif tersebut berarti terdapat pengaruh antara profitabilitas terhadap nilai perusahaan atau semakintinggi profitabilitas maka nilai perusahaan akan semakin meningkat.

$\mathrm{b}_{3}=-0,003185$ menunjukkan koefisien regresi likuiditas bernilai negatif terhadap nilai perusahaan. Artinya apabila variabel likuiditas meningkat sebesar satu $\%$, maka nilai perusahaan akan berkurang $0,003185 \%$ dengan asumsi variabel struktur modal, profitabilitas, dan ukuran perusahaan konstan.

$\mathrm{b}_{4}=-0,126623$ menunjukkan koefisien regresi ukuran perusahaan bernilai negatif terhadap nilai perusahaan. Artinya apabila variabel ukuran perusahaan meningkat sebesar satu satuan, maka nilai perusahaan akan menurun sebesar 0,126623 satuan dengan asumsi variabel struktur modal, profitabilitas, dan likuiditas konstan.

1. Pengaruh Struktur Modal Terhadap Nilai Perusahaan Nilai $t_{\text {hitung }}>t_{\text {tabel }}(5,450062>1,66177)$ dan nilai probabilitas $<0,05$ yaitu 0,0000 , berarti variabel struktur modal berpengaruh positif dan signifikan terhadap nilai perusahaan. Berdasarkan hasil pengujian tersebut, maka hipotesis pertama pada penelitian ini diterima secara statistik. Semakin besar struktur modal maka nilai perusahaan juga semakin baik. Hal tersebut dapat dijelaskan bahwa adanya kebijakan penambah hutang akan berpengaruh positif bagi persepsi dan langkah inverstor terhadap nilai 
Tunggul Priyatama dan Eka Pratini, Pengaruh Struktur Modal, Profitabilitas, Likuiditas, dan Ukuran Perusahaan terhadap Nilai Perusahaan (Studi Empiris pada Perusahaan Infrastruktur, Utilitas, dan Transportasi yang Terdaftar di Bursa Efek Indonesia Periode 2015-2018)

perusahaan karena adanya penghematan pajak di dalamnya. Dengan memasukkan pajak penghasilan perusahaan, maka penggunaan hutang akan meningkatkan nilai perusahaan karena biaya bunga hutang adalah biaya yang mengurangi pembayaran pajak (Utami, Santoso, dan Pranaditya, 2017). Hutang yang tinggi dapat memperbesar risiko perusahaan mengalami kebangkrutan, akan tetapi selama tingkat penggunaan hutang tersebut masih dalam batas optimal maka penggunaan hutang masih dalam kondisi aman (Ramdhonah, Solikin, dan Sari, 2019). Hasil penelitian ini sejalan dengan penelitian terdahulu yang dilakukan oleh Asif dan Aziz (2016), Kamila dan Yuniati (2017), Chasanah dan Adhi (2017), dan Utami, Santoso, dan Pranaditya (2017).

2. Pengaruh Profitabilitas Terhadap Nilai Perusahaan

Nilai $t_{\text {hitung }}>t_{\text {tabel }}(3,730883>1,66177)$ dan nilai probabilitas $<0,05$ yaitu 0,000 , berarti variabel profitabilitas berpengaruh positif dan signifikan terhadap nilai perusahaan. Berdasarkan hasil pengujian tersebut, maka hipotesis kedua yang menyatakan bahwa profitabilitas berpengaruh positif signifikan terhadap nilai perusahaan pada penelitian ini diterima secara statistik. Semakin tinggi profitabilitas maka, nilai perusahaan juga semakin baik. Hal tersebut dapat dijelaskan bahwa tingginya profitabilitas dapat menunjukkan prospek perusahaan yang baik kepada para investor karena para investor akan tertarik pada perusahaan yang memiliki profitabilitas yang baik, sehingga berpengaruh terhadap peningkatan permintaan saham (Chasanah, dan Adhi, 2017). Banyaknya permintaan investor akan saham perusahaan memicu kenaikan pada harga saham perusahaan tersebut. Tinggi rendahnya harga saham yang terbentuk mempengaruhi nilai dari perusahaan (Sari dan Priyadi, 2016). Hasil penelitian ini sejalan dengan Sabrin, Sarita, Takdir S. dan Sujono (2016), Sucuahi dan Cambarihan (2016), Sari dan Priyadi (2016), dan Oktaviarni, Murni dan Suprayitno (2019).

3. Pengaruh Likuiditas Terhadap Nilai Perusahaan

Nilai $\mathrm{t}_{\text {hitung }}<\mathrm{t}_{\text {tabel }}(-2,140257<1,66177)$ dan nilai probabilitas $<0,05$ yaitu 0,0350 , berarti variabel likuiditas berpengaruh negatif dan signifikan terhadap nilai perusahaan. Berdasarkan hasil pengujian tersebut, maka hipotesis ketiga yang menyatakan bahwa likuiditas berpengaruh positif signifikan terhadap nilai perusahaan pada penelitian ini ditolak secara statistik. Hasil penelitian menunjukkan bahwa semakin tinggi likuiditas, maka nilai perusahaan akan menurun. Hal tersebut dapat dijelaskan bahwa tingkat likuiditas yang tinggi akan membuat perusahaan lebih mengalokasikan dananya pada pelunasan kewajiban jangka pendek sehingga dividen yang dibayarkan kepada pemegang saham akan rendah (Yuliana, 2016). Tingkat likuiditas yang tinggi pada perusahaan infrastruktur, utilitas, dan transportasi akan menjadi sinyal negatif untuk para investor yang membuat investor tidak tertarik untuk melakukan investasi. Dengan begitu permintaan saham akan menurun, harga saham akan semakin rendah sehingga berdampak pada nilai perusahaan yang menurun (Yuliana, 2016). Hasil penelitian ini sejalan dengan Wijaya dan Purnawati (2013), Yuliana (2016), dan Andriani dan Rudianto (2019).

4. Pengaruh Ukuran Perusahaan Terhadap Nilai Perusahaan

Nilai $t_{\text {hitung }}<\mathrm{t}_{\text {tabel }}(-2,095404<1,66177)$ dan nilai probabilitas $<0,05$ yaitu 0,0389 berarti ukuran perusahaan berpengaruh negatif dan signifikan terhadap nilai perusahaan. Berdasarkan hasil pengujian tersebut, maka hipotesis keempat yang menyatakan bahwa ukuran perusahaan berpengaruh positif signifikan terhadap nilai perusahaan pada penelitian ini ditolak secara statistik. Hasil penelitian menunjukkan bahwa semakin besar ukuran perusahaan, maka nilai perusahaan semakin menurun. Hal tersebut dapat dijelaskan karena investor yang menganggap bahwa perusahaan yang memiliki total aset besar cenderung menetapkan laba ditahan lebih besar dibandingkan dengan dividen yang dibagikan kepada para pemegang saham. Perusahaan tidak selalu membagikan dividen kepada para pemegang saham tetapi mengalokasikan laba ditahan untuk digunakan sebagai modalnya kembali, hal ini terkait dengan kebijakan dividen perusahaan. Perusahaan yang mempertahankan laba daripada membaginya sebagai dividen dapat mempengaruhi harga saham dan nilai perusahaannya (Ramdhonah, Solikin, dan Sari, 2019). Kondisi tersebut dapat mengurangi minat investor pada saham perusahaan terkait, sehingga turunnya demand (permintaan) saham perusahaan akan mengarahkan pada turunnya nilai perusahaan tersebut. Hasil penelitian ini sejalan dengan penelitian yang dilakukan oleh Kamila dan Yuniati (2017), Utomo dan Christy (2017), Panggabean (2018), dan Ramdhonah, Solikin, dan Sari (2019).

\section{SIMPULAN}

Hasil penelitian ini membuktikan bahwa struktur modal dan profitabilitas berpengaruh positif signifikan terhadap nilai perusahaan. Penambahan hutang dalam struktur modal perusahaan tidak selalu berdampak negatif, karena dapat digunakan sebagai tambahan dana investasi maupun penghematan pajak perusahaan. Penghematan pajak bagi perusahaan yang melakukan hutang akan meningkatkan laba bersih yang menjadi hak pemegang saham menjadi lebih besar dibandingkan dengan perusahaan yang tidak menggunakan hutang (Dewi dan Wirajaya, 2013). Sehingga, penambahan hutang menjadi hal yang menarik bagi investor dan dapat meningkatkan nilai perusahaan. Kemudian, 
Tunggul Priyatama dan Eka Pratini, Pengaruh Struktur Modal, Profitabilitas, Likuiditas, dan Ukuran Perusahaan terhadap Nilai Perusahaan (Studi Empiris pada Perusahaan Infrastruktur, Utilitas, dan Transportasi yang Terdaftar di Bursa Efek Indonesia Periode 2015-2018)

peningkatan nilai profitabilitas dapat menunjukkan prospek perusahaan yang baik kepada para investor karena mereka tertarik pada perusahaan yang memiliki profitabilitas yang baik, dan berpengaruh pada peningkatan permintaan saham dan nilai perusahaan. Sementara itu, likuiditas dan ukuran perusahaan memiliki pengaruh negatif signifikan terhadap nilai perusahaan. Hal ini menunjukkan tingkat likuiditas yang tinggi akan membuat perusahaan lebih mengalokasikan dananya pada pelunasan kewajiban jangka pendek sehingga dividen yang dibayarkan kepada pemegang saham akan rendah. Ukuran perusahaan yang terlalu besar dianggap akan menetapkan laba ditahan lebih besar dibandingkan dengan dividen yang dibagikan kepada para pemegang saham.

Penelitian ini menghasilkan implikasi manajerial yang dapat digunakan sebagai bahan pertimbangan dan evaluasi bagi perusahaan di sektor infrastruktur, utilitas, dan transportasi. Perusahaan sektor tersebut agar dapat menentukan kebijakan selanjutnya mengenai pentingnya hutang dalam struktur modal, serta profitabilitas bagi perusahaan. Hutang boleh dilakukan selama tingkat penggunaan hutang tersebut masih dalam batas optimal, yaitu kondisi yang masih menjaga keseimbangan antara risiko dan tingkat pengembaliannya (Ramdhonah, Solikin, dan Sari, 2019). Pihak perusahaan perlu memahami bahwa adanya hutang dapat menimbulkan biaya bunga hutang yang dapat mengurangi pembayaran pajak. Biaya pajak dihitung dari laba operasi setelah dikurangi bunga hutang. Sehingga, laba bersih yang menjadi hak pemegang saham akan menjadi lebih besar dibandingkan dengan perusahaan yang tidak menggunakan hutang (Dewi dan Wirajaya, 2013). Hal tersebut menjadi menarik bagi para investor dan dapat menjadikan nilai perusahaan meningkatkan. Profitabilitas tidak bisa dikesampingkan dari salah satu tujuan penting pencapaian kinerja perusahaan. Karena mayoritas stakeholder, khususnya investor menitikberatkan perhatian pada profitabilitas ini. Perusahaan tetap harus berusahan untuk menjaga agar profitabilitas berada pada kondisi yang baik. Hal tersebut berperan untuk dapat meningkatkan performa dan nilai perusahaan. Pada poin ini, ditunjukkan bahwa suatu kebijakan dapat mengarahkan persepsi dan penilaian dari para investor yang nampaknya selaras dengan teori sinyal yang dikembangkan oleh (Ross, 1997). Perusahaan ada kalanya harus dapat memahami dan memainkan sudut pandang dari pihak eksternal, khususnya investor untuk dapat mengambil kebijakan yang sesuai dengan harapan mereka.

Penelitian ini masih ada beberapa keterbatasan, oleh karena itu, masih ada celah untuk dapat dilakukan penelitian selanjutnya. Adapun saran yang dapat dilakukan untuk penelitian berikutnya adalah dengan mempertimbangkan penggunaan variabel lain dari sudut pandang kepemilikan saham, tata kelola perusahaannya, dan berbagai aspek lain untuk dapat melihat sejauh mana faktor-faktor tersebut mempengaruhi nilai perusahaan pada perusahaan di sektor infrastruktur, utilitas, dan transportasi. Rentang waktu penelitian dapat dikaji dengan lebih lama untuk dapat memberikan hasil penelitian yang lebih kuat, dengan menggunakan tahun terbaru.

\section{DAFTAR PUSTAKA}

Andriani, P. R., \& Rudianto, D. (2019). Pengaruh Tingkat Likuiditas, Profitabilitas dan Leverage Terhadap Nilai Perusahaan pada Subsektor Makanan dan Minuman yang Tercatat di BEI (BEI) Periode 2010-2017. Journal of Entrepreneurship, Management and Industry (JEMI), 2(1), 48-60.

Anisyah \& Purwohandoko. (2017). Pengaruh Profitabilitas, Leverage, Ukuran Perusahaan dan Struktur Modal Terhadap Nilai Perusahaan pada Sektor Pertambangan yang Terdaftar pada Bursa Efek Indonesia Periode 2010-2015. Jurnal manajerial bisnis, 1(1), 34-46.

Asif, A. \& Aziz, B. (2016). Impact of Capital Structure on Firm Value Creation- Evidence from the Cement Sector of Pakistan. International Journal of Research in Finance \& Marketing, 6(6), 22315985.

Bursa Efek Indonesia. (2019). Data Pasar. https://www.idx.co.id/data-pasar/datasaham/daftar-saham/, Diakses pada tanggal 4 Oktober 2019.

Chasanah, A. N. \& Adhi, D. K. (2017). Profitabilitas, Struktur Modal Pengaruhnya terhadap Nilai Perusahaan pada Perusahaan Real Estate yang Listed di BEI Tahun 2012-2015. Fokus Ekonomi: Jurnal Ilmiah Ekonomi, 12(2), 109-128.

Deil, S. (2015). Investor Masih Tergila-gila dengan Sektor Saham Infrastruktur RI. https://www.liputan6.com/bisnis/read/2188583/in vestor-masih-tergila-gila-dengan- sektor-sahaminfrastruktur-ri. Diakses pada tanggal 1 Maret 2020.

Deli, E. P. I. N. \& Kurnia. (2017). Pengaruh Struktur Modal, Profitabilitas, Growth Opportunity dan Likuiditas Terhadap Nilai Perusahaan. Jurnal Ilmu dan Riset Akuntansi, 6(7).

Dewi, A. S. M., \& D. Wirajaya. (2013). Pengaruh Struktur Modal, Profitabilitas, dan Ukuran Perusahaan pada nilai Perusahaan. Jurnal Akuntansi, 4(2).

Fauzi, M. S. \& Aji, T. S. (2018). Pengaruh Struktur Modal, Ukuran Perusahaan dan Profitabilitas terhadap Nilai Perusahaan Sektor Agriculture Tahun 2012-2015. Jurnal Manajemen Fakultas Ekonomi Universitas Negeri Surabaya, 6(1).

Gujarati, D. N. \& Porter, D. C. (2010). Dasar-Dasar 
Tunggul Priyatama dan Eka Pratini, Pengaruh Struktur Modal, Profitabilitas, Likuiditas, dan Ukuran Perusahaan terhadap Nilai Perusahaan (Studi Empiris pada Perusahaan Infrastruktur, Utilitas, dan Transportasi yang Terdaftar di Bursa Efek Indonesia Periode 2015-2018)

Ekonometrika. Edisi 5, Buku 2. Jakarta; Salemba Empat.

Kamila, D. R., \& Yuniati, T. (2017). Pengaruh Ukuran Perusahaan, Leverage, Profitabilitas dan Struktur Modal terhadap Nilai Perusahaan. Jurnal ilmu dan riset manajemen, 6(3).

Kevin, A. (2018). Kinerja Sektoral Kuartal I, Pertambangan Naik Paling Tinggi. https://www.cnbcindonesia.com/market/20180402 161126-17-9383/kinerja- sektoral-kuartal-ipertambangan-naik-paling-tinggi. Diakses pada tanggal 1 Maret 2020.

Kurniasih, B., \& Ruzikna. (2017). Pengaruh Struktur Modal dan Keputusan Investasi Terhadap Nilai Perusahaan pada Industri Makanan dan Minuman yang Terdaftar di Bei. JOM FISIP, 4(2).

Mawarni, P. I., \& Triyonowati. (2017). Pengaruh Struktur Modal dan UkuranPerusahaan Food and Beverages. Jurnal ilmu dan riset manajemen, 6(6).

Oktaviarni, F., Murni, Y., \& Suprayitno, B. (2019). Pengaruh Profitabilitas, Likuiditas, Leverage, Kebijakan Dividen dan Ukuran Terhadap Nilai Perusahaan (Studi Empiris Perusahaan Sektor Real Estate, Properti, dan Konstruksi Bangunan yang Terdaftar di Bursa Efek Indonesia Tahun 2014-2016). Jurnal Akuntansi, 9(1), 1-16.

Panggabean, M. R. (2018). Pengaruh Corporate Social Responsibility, Ukuran Perusahaan, Struktur Modal dan Tax Avoidance terhadap Nilai Perusahaan (Pada Perusahaan Manufaktur yang Masuk dalam Lq45 di Bursa Efek Indonesia Periode 2011-2017). Jurnal Kajian Bisnis, 26(1).

Putra, A. A. N. D. A. \& Lestari P. V. (2016). Pengaruh Kebijakan Dividen, Likuiditas, Profitabilitas Dan Ukuran Perusahaan Terhadap Nilai Perusahaan. E-Jurnal Manajemen Unud, 5(7), 4044 - 4070.

Ramdhonah, Z. I. S., \& Sari, M. (2019). Pengaruh Struktur Modal, Ukuran Perusahaan, Pertumbuhan Perusahaan, dan Profitabilitas terhadap Nilai Perusahaan (Studi Empiris Pada Perusahaan Sektor Pertambangan yang Terdaftar di Bursa Efek Indonesia Tahun 2011-2017). Jurnal Riset Akuntansi Dan Keuangan, 7(1).

Riyanto, B. (2008). Dasar-Dasar Pembelanjaan Perusahaan. BPFE. Yogyakarta.

Ross, S. A. (1977). The Determination of Financial Structure: The Incentive-Signalling Approach. The Bell Journal of Economics, 8(1), 23-40.

Sabrin., Sarita, B., Syaifuddin, D. T., \& Sujono. (2016). The Effect of Profitability on Firm Value in Manufacturing Company at Indonesia Stock Exchange. The International Journal of Engineering and Science, 5(10), 81-89.

Sari, R. A. I. \& Priyadi, M. P. (2016). Pengaruh Leverage, Profitabilitas, Size, Dan Growth Opportunity Terhadap Nilai Perusahaan. Jurnal
Ilmu dan Riset Manajemen, 5(10).

Spence, M. (1973) "Job Market Signaling". The Quarterly Journal of Economics, 87(3), (Aug., 1973), pp. 355-374. The MIT Press.

Sucuahi, W. \& Cambarihan, J. M. (2016). Influence of Profitability to the Firm Value of Diversified Companies in the Philippines. Accounting and Finance Research, 5(2). 149-153.

Suranto, V. A. H. M., Nangoi, G. B., \& Walandouw, S. K. (2017). Pengaruh Struktur Modal dan Kinerja Keuangan Terhadap Nilai Perusahaan pada Perusahaan Perbankan di Bursa Efek Indonesia. JurnalEMBA, 5(2), 1031-1040.

Tui, Sutardjo., Nurnajamuddin, M., Sufri, M., \& Nirwana, A. (2017). Determinants of Profitability and Firm Value: Evidence from Indonesian Banks. International Journal of Management \& Social Sciences, 7(1), 84-95.

Utami, D., Santoso, E. B., \& Pranaditya, A. (2017). Pengaruh Struktur Modal, Pertumbuhan Perusahaan, Profitabilitas, Ukuran Perusahaan, Kinerja Keuangan Perusahaan, Terhadap Nilai Perusahaan (Studi Kasus Perusahaan Manufaktur Sektor Aneka Industri yang Terdaftar di Bursa Efek Indonesia tahun 2011-2015). Journal of Accounting, 3(3).

Utomo, N. A. \& Christy, N. N. A. (2017). Pengaruh Struktur Modal, Profitabilitas, Ukuran Perusahaan Terhadap Nilai Perusahaan Pada Perusahaan Lq 45 Di Bursa Efek Indonesi. Bima Bingkai Manajemen, STIE DharmaputraSemarang.

Wiagustini, Ni Luh Putu. (2010). Manajemen Keuangan. Udayana University Press. Denpasar.

Widiastari, P. A., \& Yasa, G. W. (2018). Pengaruh Profitabilitas, Free Cash Flow dan Ukuran Perusahaan pada Nilai Perusahaan. E-Jurnal Akuntansi Universitas Udayana, 23(2), 957-981.

Wijaya, I. B. N. P., \& Purnawati, N. K. (2013). Pengaruh Likuiditas dan Kepemilikan Institusional derhadap Nilai Perusahaan Dimoderasi Oleh Kebijakan Dividen. Fakultas Ekonomi Dan Bisnis Universitas Udayana.

Yuliana, S. R. (2016). Pengaruh Likuiditas, Pertumbuhan Perusahaan (Growth), Leverage dan Profitabilitas terhadap Nilai Perusahaan (Studi Pada Perusahaan Manufaktur yang Terdaftar di Bursa Efek Indonesia Periode 2011-2015). Fakultas Ekonomi Dan Bisnis Universitas Muhammadiyah Yogyakarta. 